\title{
Friluftsliv, religion og stillhet
}

\section{Av Ola Hellenes}

Når vi jobber med ulike temaer i skolen, er det stadig en utfordring å kunne lage opplegg som er spennende, praktisk orienterte og som man samtidig kan lare noe av. Denne artikkelen presenterer og reflekterer over et fors $\emptyset \mathrm{k}$ fra min side på å lage et interessant tverrfaglig opplegg mellom religion og friluftsliv for folkehøyskoleelever. ${ }^{1}$ Opplegget ble brukt i rammen av folkehøyskole, men jeg tror det kan gi inspirasjon til lignende opplegg i offentlig skole eller brukes innenfor trosopploring.

OLA HELLENES, lœerer ved Universitetet i Sør-Øst Norge. E-post: ola.hellenes@usn.no

I folkehøyskolen har man brede dannelsesmål og stort rom for å prøve ut ny undervisning. I mitt arbeid valgte jeg å fokusere på kristendom og forholdet til naturen der, og å anvende ressurser fra en kristen tradisjon som er kjent for å ha en sterk kobling til naturen: nemlig keltisk spiritualitet. Spørsmålet mitt er: Hvordan legge til rette for folkehøyskole-elevers refleksjon og opplevelse av natur og tro, og gi dem innblikk i keltisk kristen spiritualitet? I denne artikkelen vil jeg presentere praksisen, bakgrunnen for den og refleksjoner over den.

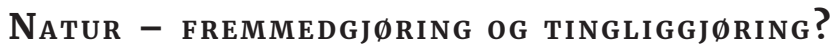

Mange mener at mennesket i en stadig mer urbanisert og globalisert verden blir mer fremmedgjort fra naturen enn tidligere. Dette gjelder både når det kommer til det å føle seg som en del av den naturen man er så avhengig av, men også det at man ikke har kontakt med naturens rytme, som gjennom tidene har vært viktig for menneskets psyke og livsstil. En hektisk livsstil preget av et jag etter opplevelser, inntrykk og raske løsninger på livets utfordringer, er noe av det som preger den postmoderne tiden vi lever i (Gelter 2007:40). Som et svar på den fremmedgjøringen mennesket står overfor i forhold til naturen, trengs en positiv miljøutdanning for å kunne få en relasjon til naturen igjen. Gelter mener at en god innfallsvinkel til dette ikke kun er å gi unge teoretisk kunnskap om natur og miljø, men også genuine møter med naturen, hvor naturen er i sentrum. Naturens egenverdi vil da ifølge Gelter, påvirke den unges holdninger til naturen. Dette synet står i en typisk tradisjon etter for eksempel Nils Faarlunds tanker om naturen (som Gelter også oppgir som en inspirasjonskilde) eller også Arne Næss sin økofilosofi som var inspirert av et nært forhold til natur (Tordsson 2006:100). Det didaktiske opplegget jeg utarbeider, kan slik jeg ser det, være med på å

1 Artikkelen er et resultat av et arbeid i en praksisperiode jeg gjennomførte på en folkehøyskole mens jeg studerte frilufts- og religionsdidaktikk på Notodden. 
gi unge mennesker et slikt møte eller erfaring med naturen som kan føre til at synet på den endres. I dette ligger det fra min side et mål om at dette kan være en del av en dannelsesprosess.

Det at naturen er blitt mer fremmed for oss, kan også ha en sammenheng med at vi ser oss selv som «annerledes» i forhold til den, eller at vi «tingliggjør» naturen. Alister McGrath skriver i sin bok The re-enchantment of nature om hvordan det moderne menneske har sluttet å se seg selv i relasjon med naturen, men heller som et vesen som står over naturen, og derfor kan utnytte den slik man vil. Dette har ført til en destruktiv holdning til natur, hvor naturen kun er en ressurs uten verdi i seg selv. (McGrath 2002)

\section{KeLTiSK SPIRITUALITET}

I prosessen med å velge ut et teoretisk grunnlag for opplegget mitt unders $ø$ kte jeg ulike kilder og retninger innenfor kristen tro som har natur som et tydelig tema. Jeg fant ut at det er mye man kunne nevnt, og i mange tradisjoner er natur viktig. Man trenger ikke å gå lengre enn til for eksempel den norske salmetradisjonen for å finne eksempler på at natur inspirerer den som tror, og står sentralt i tekstene. (Sæther 2013)

Jeg landet på den keltiske tradisjonen fordi det allerede er mye som er skrevet om temaet, og at det virker å være et spesielt godt eksempel på en kristen tradisjon hvor natur står sentralt. Keltisk kristendom har gamle røtter. En teori er at kristendommen ankom keltiske områder gjennom påvirkning fra ørkenfedrene, ved at munker ankom øyene og grunnla tidlige klostre. Dette kan forklare noe av fokuset på klosterliv og kontemplativ spiritualitet som man finner i keltisk spiritualitet også i dag (Olsen 2008). Sentrene i den keltiske kristendommen var ofte knyttet til vakre steder omgitt av natur. Man kan tenke seg at det derfor var naturlig at naturen ble en viktig del av deres spiritualitet (Laursen 2012:140). Keltiske bønner og historier har blitt samlet inn og oversatt til engelsk slik at keltisk tradisjon og tankegods har blitt mer tilgjengelig (Laursen 2013:141, Rosemary 2006:34). I undervisningen har jeg valgt å bruke noe av dette materialet for å gi eksempel på hvordan keltisk spiritualitet kunne uttrykkes.

Moderne former for keltisk kristen spiritualitet kommer til uttrykk i ulike populære bevegelser som årlig samler mange tilreisende på de britiske øyer. I dag er det for eksempel et pulserende liv både på Lindisfarne og øya Iona langs den skotske kysten. Den moderne keltiske kristne spiritualiteten kjennetegnes av:

- En interesse og respekt for natur og varhet for Gud som immanent i naturen

- En ortodoks forståelse av kristen lære. For eksempel i forhold til treenigheten. Det vil si at disse miljøenes teologi stort sett kan «godtas» av andre kristne trossamfunn.

- En spesiell stedsforståelse, gjerne knyttet til pilegrimsvandring og klostre. 
Her finnes det også en oppfatning om at man på visse steder enklere kommer i kontakt med Gud.

- Likestilling mellom kvinne og mann

- En oppfattelse av at spontanitet i lovsang og liturgi har preget keltiske kirker

- Kunst og musikk som viktige uttrykksformer

- Skepsis til kirkelige strukturer, men en bevissthet om egen historie og et forhold til åndelige forbilder fra tradisjonene. (Rosemary 2006:34-35)

\section{Spiritualitet}

Jeg har allerede brukt ordet «spiritualitet» flere ganger. Hva mener jeg med det? Begrepet ble først brukt i den katolske kirke i forbindelse med askese og mystikk, senere i forbindelse med nyreligiøsitet og verdensreligioner. I det siste er begrepet også brukt innenfor all slags kristen litteratur, og også som et sekulært begrep som beskriver menneskers tilknytning til spørsmål om mening, liv, $\mathrm{d} \emptyset \mathrm{d}$, skyld, rettferdighet, lidelse og tid. Det finnes et mylder av ulike definisjoner av spiritualitets-begrepet, men ifølge Harald Olsen er et kjennetegn ved alle religiøse definisjoner at de snakker om menneskers «levde erfaring» av religionen. Olsen definerer selv spiritualitet som «troens ytringsformer og manifestasjoner slik de kommer til uttrykk i menneskers liv ...» (Sæther 2013:23-25). Selv bruker jeg ordet spiritualitet på en lignende måte, hvor begrepet rett og slett beskriver hvordan mennesker utøver og opplever troen i livet sitt.

\section{Praksis: hVA, hVordan og hVorfor?}

$\AA$ jobbe med et undervisningsopplegg i folkehøyskolen er ganske annerledes enn å skulle lage en undervisningstime i den offentlige skolen. Dette er særlig på grunn av at de pedagogiske grunntankene er ulike. I folkehøyskolen har man tradisjonelt lagt vekt på den praktiske læring, og nedtonet det teoretiske, mens man i den vanlige offentlige skole har lagt mer vekt på kunnskapsformidling $\mathrm{i}$ form av teori. At folkehøyskolen er annerledes, kommer blant annet til uttrykk i folkehøyskoleloven, som sier at det ikke skal gis karakterer. Når det kommer til religionsfaget i den offentlige skolen holdes det gjerne fram at en kan observere religion og lære om den, mens man er skeptisk til å skulle lære $a v$ religion (Andreassen 2012). A praktisere religion eller skulle gjøre noe som ses på som en åndelig praksis, oppfattes som problematisk i offentlig skole.

\section{DANNELSE I FOLKEHØYSKOLEN OG DE OFFENTLIGE SKOLENE}

Når jeg skal skrive om opplegget mitt, er et sentralt begrep jeg kommer til å komme innom, dannelse. Dannelse er et ord som brukes i mange læreplaner og i skoleverket generelt. 
Et mål som går igjen når man leser om folkehøyskoler er at de skal bidra til å danne elevene. Dannelsesprosessen i folkehøyskolen går særlig ut på å lære seg sosial kompetanse og å leve sammen med andre, noe som blant annet skal skje ved at elevene bor sammen. Historisk sett var folkehøyskolen uttrykk for en reaksjon mot latinskolen og den instrumentalistiske puggeskolen. Folkeh øyskolen skulle, i motsetning til teoretiske latinskoler, være en plass hvor man lærte med hode og hender, og hvor elevene kunne utvikles som hele mennesker (Grundtvig 1830). I folkehøyskolen er dannelsesbegrepet linket opp mot å tilegne seg fysiske erfaringer, og skal man tro Grundtvig, er det i et fellesskap som gjør sammen at man finner glede og utspring for kreativitet og energi. Dette danner mennesker som er i stand til å omsette sin kraft til gavn for samfunnet og glede for seg selv.

I grunnskolen kan det for meg virke som at dannelsesbegrepet handler mer om kunnskap enn i folkehøyskolen, men her har det selvsagt skjedd store forandringer siden 1800 -tallets puggeskoler. Her er et nyansert eksempel sakset fra den nye overordnede delen av læreplanen:

Danning skjer når elevene får kunnskap om og innsikt i natur og miljø, språk og historie, samfunn og arbeidsliv, kunst og kultur, og religion og livssyn. Danning skjer også gjennom opplevelser og praktiske utfordringer i undervisningen og skolehverdagen ... Elevene dannes $i$ møte med andre og gjennom fysisk og estetisk utfoldelse som fremmer bevegelsesglede og mestring. (regjeringen.no 2017)

Jeg mener at om man ønsker å ta målet om dannelse i skolen seriøst, må dette også reflekteres i hvordan vi underviser. Ønsker vi å skape for eksempel en respekt for natur blant unge, nytter det ikke bare å snakke om natur, men man må ut og oppleve den og få positive opplevelser ikke bare i naturen, men med naturen. Dette er også sant for ulike opplegg i trosopplæring i kirke eller menighet, og her har man alle muligheter til å prøve.

\section{KRISTEN FOLKEH $\emptyset$ YSKOLE}

Den skolen jeg skulle ha praksis på, Valdres folkehøyskole, er en kristen folkehøyskole, noe som blant annet reflekteres på skolens nettsider.

Vi ønsker at du skal få erfare at kristen tro kan vœre:

- Nestekjœrlighet i praksis, lokalt og globalt.

- Livsglede og engasjement.

- Omsorg for skaperverket; naturen og oss mennesker. (vintereventyr.no)

På nettsidene presenterer skolen eier-organisasjonen KFUK/KFUM sitt formål: Vårt formål er å utvikle og ta ansvar for hele mennesket med ånd, sjel og kropp. Vi vil hjelpe mennesker å leve og vokse i tro på Jesus Kristus og mellommenneskelig forståelse, 
samt utfordre til engasjement og handling i kirke og samfunn, lokalt og globalt.

(vintereventyr.no)

Slik jeg ser det ligger det i disse formålstekstene et betydelig fokus på dannelse, slik det generelt sett er tenkt i folkehøyskolen. Å utvikle ånd, sjel og kropp, leve og vokse i tro og utfordre til engasjement og handling er alle uttrykk som passer som hånd i hanske i forhold til dannelses-begrepet vi tidligere har sett på.

\section{Det allmennmenneskelige og allmenNRELigiøSe}

Når jeg skulle planlegge et opplegg for en folkehøyskole-klasse som jeg visste representerte et livssynsmessig mangfold, var det viktig for meg at opplegget var for alle, og ikke kun for dem som hadde et spesielt livssyn.

I religionsdidaktikk snakker man om allmennmenneskelige, religiøse og religionsspesifikke sider av et bestemt livssyn. De allmennmenneskelige sidene er noe alle mennesker kan gjenkjenne seg i, lære av og ta til seg, det religiøse er sider ved en religion med innhold som er felles for flere religioner, mens det religionsspesifikke vil være innhold i religionen som er spesifikt for den ene religionen. (Beidlid og Nicolaisen: 2011:62-64)

Med bakgrunn i disse innsiktene ønsket jeg å utforme et opplegg som inneholdt alle disse sidene. Rent pedagogisk sett fant jeg det best å starte med det allmennmenneskelige (opplevelse av stillhet i naturen), før jeg fortsatte til en religiøs del (et eksempel på en bønn til Gud) før jeg presenterte en mer religionsspesifikk del (litt om keltisk kristendom og noen tekster som knyttes til dette, og en salme i bibelen). Her skal det sies at jeg ikke ser en streng grense mellom de tre delene, det finnes glidende overganger, og alle vil kunne lære noe av de ulike delene.

I mitt opplegg var det også viktig at jeg ikke la press på elevene i forhold til det at de følte at de ble tvunget til å gjøre noe de ikke ville. Derfor var det jeg la fram forslag til hva man kunne gjøre, hvor jeg foreslo ulike ting man kunne gjøre. Det vil si at eleven for eksempel hadde muligheten til å lese tekstene, og muligheten til å la være. Eleven hadde muligheten til å be, men kunne selvsagt også gjøre noe helt annet. Selvfølgelig måtte elevene høre på de tekstene jeg leste opp, men jeg tenker at dette i seg selv ikke betyr at man blir aktivt deltakende i en religiøs praksis. Eleven må enkelt nok observere eller lytte til en tekst eller bønn som er en del av den menneskelige kulturhistorien.

I et friluftslivsperspektiv vil man kunne si at man er en veileder, som legger til rette for en situasjon som innbyr til læring. Jeg tror det er noe av dette friluftspedagogen Bjørn Tordsson snakker om her:

Skulle man dele friluftslivets vardier og glceder med andre, måtte selve formerne for opplæring åbne for at naturen, sådan som den opfører sig i de konkrete situasjoner, blev den virkelige laremester. (Tordsson 2006:190) 
Jeg ser det slik at jeg i mitt opplegg vil tilrettelegge for en situasjon og gi innføring i noen perspektiver som kan, men ikke må, føre til en slags dannelsesprosess hos eleven. Eleven velger selv hva den tar med seg og hva den kaster ut i forglemmelsens hav.

\section{Praksis: gjennomføring}

Hva gjorde jeg? Den praktiske gjennomføringen gikk for seg slik som dette:

Jeg gav på forhånd litt info om hva som skulle skje, slik at elevene blant annet var forberedt på stillhet. Elevene ble bedt om å ta med noe å notere på. Vi dro til et sted jeg hadde sett ut på forhånd med noen ønskede naturkvaliteter: god utsikt, gammel skog og ikke for langt å gå.

Da vi kom fram med bussen, vandret vi først langs en sti, uten at jeg presenterte noe mer om hva vi skulle gjøre, annet enn ca hvor langt det var å gå. Jeg hadde vurdert å gjøre det slik at alle elevene måtte være stille også da vi gikk inn til plassen, men jeg fant ut at det ville være en god overgang fra mye lyd til stillhet å kun gå foran og vise et eksempel ved å være stille. Folk kunne snakke sammen, men de fleste var lavmælte.

Jeg gikk foran i rolig tempo, og jeg stoppet gruppa en gang i løpet av turen (som tok ca 15-20 minutter). Under stoppet gav jeg elevene i oppgave å plukke med ved underveis, og jeg forklarte hvordan jeg vanligvis forsøker å finne ved på bakken om det er mulig. Dette gjorde jeg for at elevene skulle kunne lære noe om respekt for naturen, og var et fors $ø \mathrm{k}$ på å praktisk med ord og kroppslig handling innarbeide noe jeg tenker fører til dannelse. Jeg gav informasjonen $i$ kontekst av en gammel furu som jeg forklarte at kunne stå i mange hundre år før den døde, før den igjen kunne stå/ligge i nesten like mange år etter at den var $\mathrm{d} \emptyset \mathrm{d}$. Det at vi hadde ved når vi kom fram, gjorde at jeg slapp å fly rundt og forstyrre elevene i deres stilletid.

Da alle var kommet fram til toppen av kollen, la vi fra oss veden i en haug, og jeg fortalte hva som var retningslinjene for den neste timen:

- Ingen kommunikasjon

- Ingen teknologi

- At man skulle forsøke ikke å forstyrre andre, både ved å lage lyd eller være urolig

- Når jeg gav signal (plystring) skulle alle komme tilbake til bålplassen, mens de fremdeles var stille.

Deretter sa jeg at alle kunne finne seg et sted, være rolige og bruke tiden slik de selv ønsket. 


\section{Samling}

Etter en times stillhet samlet jeg elevene slik at de satt rundt et bål (som enda ikke var tent), slik at alle kunne se hverandre. Det var litt uvant for elevene å se på hverandre uten å snakke, men det gikk greit. Da alle hadde slått seg til ro, tente jeg opp bålet, og med en gang etter at ilden var i gang, leste jeg opp «Bønn for å nøre opp ilden»:

\section{Bønn for å nøre opp ilden}

I denne morgen, mens jeg nører opp ilden, ber jeg om at Guds kjærlighets flamme må brenne i mitt hjerte, og i hjertene til alle jeg møter i dag.

Jeg ber om at ingen misunnelse og ingen ondskap, intet hat og ingen frykt må kvele flammen.

Jeg ber om at ingen likegyldighet og apati, ingen forakt og stolthet, må skylle som vann over ilden.

Måtte i stedet gnisten fra Guds kjærlighet tenne kjærligheten i mitt hjerte, slik at den kan brenne klart gjennom dagen.

Måtte jeg få varme dem som er ensomme, de som har kalde og livløse hjerter, slik at alle kan kjenne velværet av Guds kjærlighet.

Etter at jeg hadde lest opp bønnen, gav jeg elevene muligheten til å si noe om hva de erfarte under stillheten. Jeg sendte rundt en bit med bark, og når eleven hadde barkebiten, hadde den også ordet, hvis de ikke ville si noe, kunne de sende barkebiten videre. Ingen hadde lov til å kommentere det de andre sa, eller stille spørsmål. Jeg gjorde det også klart at det vi sa ble innenfor gruppa. Denne delen tok jeg med fordi jeg ønsket at elevene skulle få sette ord på opplevelsene sine, blant annet fordi metakognisjon stimulerer læring, og ved å artikulere hva man har opplevd, tror jeg man kan få mer ut av opplegget. (Tordsson 2006:124-126) I tillegg til å få satt ord på sin egen erfaring fikk alle gjennom denne dele-runden 
et innblikk i hva de andre tenkte, følte og gjorde i løpet av stilletiden. Alle $\emptyset$ nsket å dele noe.

Da alle hadde sagt sitt, lot jeg det være stille noen sekunder før jeg begynte å fortelle om hvordan bønnen om ilden var en del av Keltisk spiritualitet og hvorfor jeg leste den. Deretter snakket jeg om dette:

- Litt om vår fremmedgjøring til naturen.

- Vår kulturs fokus på natur som en kvantifiserbar ressurs, ikke dens iboende kvalitative verdi.

- Kristen tro har blitt kritisert for å underbygge dette synet.

- Tilsvar til kritikken: Det skapte som godt. Forvaltertanken.

- Naturen oppfattet som Guds andre bok. Guds immanens.

- I mange kristne tradisjoner hvor naturen har spilt en mer sentral rolle. Norske salmer. Et eksempel er keltisk kristendom.

- Kelterne hadde for vane å be ved mange anledninger, for eksempel når de tente ilden om morgenen, eller vasket ansiktet etter en lang dag. (se vedlegg s. 329)

- Klostre på øde plasser i naturen.

- Fokus på natur i bønn og poesi (se vedlegg s. 329)

Etter dette forklarte jeg også at det vi hadde gjort, i forhold til å være stille i naturen, er en viktig del av den keltiske spiritualiteten. Deretter sa jeg at studiet av natur og å observere dens mangfold, detaljrikhet og storhet for mange kristne i dag kan være en måte å utøve kristen spiritualitet på.

\section{Avsluttende stillhet}

Deretter opplyste jeg om at elevene de neste 20 minuttene enten kunne: lese tekstene som de hadde fått utdelt, studere noe i naturen nøye (slik som en plante eller en stein), be, være stille og eller bare slappe av. De samme retningslinjene for stillheten gjaldt her som ved den første.

Etter at vi hadde gjennomført den siste delen med stillhet, samlet vi igjen gruppa, før vi gikk tilbake til minibussen. Jeg takket for alles tålmodighet, før vi gikk, snakket, sprang og lekte oss tilbake mot bussen etter at stillheten var brutt.

\section{HVORDAN FUNGERTE OPPLEGGET?}

I løpet av dele-runden vi hadde ved bålet, fikk jeg et godt inntrykk av elevenes opplevelse av den første delen av opplegget. Mange trakk fram at stillheten var avslappende. Andre at det var vanskelig eller uvant å være stille, men at det gikk seg til etter hvert. Noen ble sittende og tenke på minner. Mange synes det var godt å få et avbrekk fra den sosiale hverdagen ved skolen, og for én vekket 
stillheten tanker om takknemlighet. Jeg hadde inntrykk av at elevene likte opplegget, også om de ikke hadde en kristen bakgrunn.

I etterkant av opplegget tenkte jeg igjennom hva det var jeg ville gjort annerledes, og hva som fungerte bra i opplegget jeg utarbeidet.

Jeg synes det pedagogiske fungerte i forhold til stillhet, deling og framføring av bønn. Her følte jeg at regien var god, at det var passe mye og interessant for elevene. Å velge et stille sted med villmarkspreg viste seg å være et godt trekk. I forhold til bibeltekst som jeg leste opp, tenkte jeg i etterkant at andre tekster kanskje kunne egnet seg bedre. Hadde jeg valgt tekster i dag, hadde jeg nok for eksempel ikke valgt salme 98, men heller salme 8, eller en tekst fra Kolosserne 1,15-20. Jeg ville nok også kun introdusert én annen tekst fra keltisk tradisjon i tillegg til å ta med bønnen jeg leste opp, less is more.

Hvis jeg skulle gjort det på nytt, ville jeg også hatt en lengre stille-stund på slutten. 20 minutter gikk overraskende raskt, og jeg fikk tilbakemeldinger på at opplegget gjerne kunne vært lengre. Jeg kan konkludere med at elevene satte pris på stillheten, og at de synes det var greit å få presentert et opplegg med et religiøst innhold. Mange fikk en opplevelse av at stillhet kan være noe positivt $\mathrm{i}$ deres liv, selv om de ikke var vant med dette fra før av.

\section{Avslutining}

Siden jeg utførte dette prosjektet med stillhet og kristendom i folkehøyskolen for godt over et år siden, har jeg reflektert en del over stillhet i organisert friluftsliv.

De fleste av oss som jobber med friluftsliv, har egne erfaringer med stillhet og naturopplevelse, og ofte forventer vi at elevene våre skal oppleve eller føle det samme som oss. Samtidig planlegger vi ofte ikke slik at elevene får sjansen til å få erfaringer med stillhet. Man er på et sted sammen med 20 andre sosiale vesener.

Jeg tror opplegg som dette kan være svært verdifullt i forhold til å planlegge slik at elevene opplever det vi vil at de skal.

Når det kommer til religionsfaget i skolen, tenker jeg at slike opplegg som dette kan være en etterlengtet pust i bakken for mange elever, og at de får en konkret erfaring både med den allmenne stillheten, men også en innsikt $i$ en tradisjon som kanskje gir mer mening når de selv opplever litt, enn om man bare leser om den.

Jeg tror også at man kan ha utbytte av et opplegg som dette i trosopplæring. Jeg har selv fors $\emptyset \mathrm{kt}$ meg på lignende stillhets-opplegg med ungdommer ned mot 15-16 år, noe som har fungert bra. Jeg ser for meg at for eksempel i konfirmantundervisning eller på ungdomsleirer kunne noe slikt vært aktuelt. 


\section{LITTERATUR:}

Andreassen B. O. (2012), Religionsdiaktikk - en innføring, Universitetsforlaget, Oslo.

Fiskum T.A, Husby A.H (red) (2014), Uteskoledidaktikk. Ta fagene med ut, Oslo,

Cappelen Damm.

Folkehøyskoleloven, https://lovdata.no/dokument/NL/lov/2002-12-06-72,

Gelter H., i red. Henderson B. og Vikander N.(2007). Nature first. Outdoor Life the Friluftsliv Way. Natural Heritage Books, Toronto

McGrath A. (2002), The Reenchantment of Nature. The Denial of Religion and the Ecological Crisis, Crown Publishing Group, London.

Grundtvig, N.F.S (1837), Til Nordmœend om en norsk Høi-Skole, Cristian Grøndal (trykkeri), Oslo.

Laursen A. R (2013), Veier til helhet. Lær å meditere i kristen tradisjon, Verbum forlag, Oslo.

Olsen H. (1999), Ilden fra vest. Tekster fra keltisk fromhetstradisjon, Verbum forlag, Stavanger.

Olsen H. (2008), Ørkenvind. Arven fra ørkenens fedre og mødre, Verbum forlag, Trondheim.

Regjeringen.no (2017), Overordnet del. Verdier og prinsipper for grunnopplaringen, https://www.regjeringen.no/contentassets/37f2f7e1850046a0a3f676fd45851384/ overordnet-del---verdier-og-prinsipper-for-grunnopplaringen.pdf, lest den 16.10.18.

Rosemary Power (2006), A Place of Community. "Celtic" Iona and Institutional Religion, Folklore, Routledge. http://dx.doi.org/10.1080/00155870500479919

Sødal, H. K. (Red.). (2006), Religions- og livssynsdidaktikk. En innføring, 3. utgave, Kristiansand Høyskoleforl.

Sæther K. W. (red) (2013), Kristen spiritualitet. Perspektiver, tradisjoner og uttrykksformer, Akademika forlag, Trondheim/Oslo.

Tordsson B. (2006), Perspektiv på friluftslivets pedagogikk (dansk utgave), Sønderjylland university college, Haderslev.

Vintereventyr.no, Våre verdier, http://www.vintereventyr.no/skolen/verdier/, lest den 26.05.2017. 
Jesus skulle prises

Det fins ingen plante på marken

Som ikke er full av Hans verdighet

Det fins ingen fure på stranda

som ikke er full av Hans velsignelse

Jesus, Jesus, Jesus,

Jesus! Du skulle prises!

Det fins ikke liv i havet

Ingen skapning i elva

Ingenting i himmelen

Som ikke roper ut Hans godhet

Jesus, Jesus, Jesus,

Jesus! Du skulle prises!

Det fins ingen fugl på vinger

Ingen stjerne i sky

Ingenting bak sola

Som ikke roper ut hans godhet

Jesus, Jesus, Jesus,

Jesus! Du skulle prises!

Oversatt fra Alexander Carmichael, "Carmina Gadelica”, s.39 (Av Ola Hellenes)

\section{Gud}

Jeg er vinden som puster på sjøen.

Jeg er bølgen på havet.

Jeg er hviskingen i raslende løv.

Jeg er solens lys.

Jeg er månens og stjernens stråler.

Jeg er kraften i treet som gror.

Jeg er knoppen som springer i blomst.

Jeg er bevegelsen i den svømmende laks.

Jeg er motet i det kjempende villsvin.

Jeg er hurtigheten i den løpende kronhjort.

Jeg er styrken i oksen som drar plogen.

Jeg er storheten i det mektige eiketre.

Og jeg er tankene til alle menneskene

som priser min skjønnhet og storhet.

Harald Olsen 1999, s. 81.
Salme 98

Syng en ny sang for Herren, for han har gjort under!

Hans høyre hånd og hellige arm

har gitt ham seier.

Herren har gjort sin frelse kjent, åpenbart sin rettferd for folkenes øyne.

Han husker sin miskunn, sin trofasthet mot Israels hus.

Hele jorden har sett

frelsen fra vår Gud.

Rop av glede for Herren, all jorden!

Bryt ut i jubel, syng og spill!

Syng for Herren og spill på lyre, spill på lyre, la sangen tone, spill på trompeter, la hornet klinge, rop av glede for kongens ansikt, for Herren!

Havet og alt som fyller det, skal bruse, jorden og de som bor der.

Elvene skal klappe i hender

og fjellene juble i kor

for Herrens ansikt.

For han kommer

og skaper rett på jorden.

Han skal dømme verden med rettferd og folkene med rett 